\title{
PEMBERDAYAAN MATERI AJAR BERBENTUK DIGITAL MENGGUNAKAN APLIKASI OPEN OFFICE SUN MICROSYSTEM BAGI GURU-GURU SMA SE-KECAMATAN UBUD
}

\author{
Dewa Gede Hendra Divayana1, P. Wayan Arta Suyasa², \\ I Made Agus Wirawan ${ }^{3}$, I Made Putrama ${ }^{4}$ \\ 1,2,3,4 Jurusan Pendidikan Teknik Informatika FTK Undiksha \\ Email: Hendra.Divayana@Undiksha.Ac.Id
}

\begin{abstract}
ABSTRAK
Tujuan utama diadakan kegiatan pengabdian masyarakat ini adalah: 1) untuk mengetahui tingkat pengetahuan para guru SMA di Kecamatan Ubud tentang keberadaan open office sun microsystem, 2) untuk mengetahui tingkat kemampuan para guru SMA di kecamatan Ubud dalam membuat materi ajar berbentuk digital. Metode yang digunakan dalam pelaksanaan kegiatan ini yaitu metode pelatihan. Keberhasilan pelaksanaan kegiatan ini dibuktikan dari hasil test kognitif yang didapatkan oleh peserta pelatihan dengan perolehan nilai rata-rata sebesar 80.67 , hasil test praktek dengan perolehan nilai rata-rata sebesar 81.60 , dan dari hasil respon yang diberikan oleh peserta pelatihan melalui angket, dengan perolehan prosentase sebesar $93.33 \%$.
\end{abstract}

Kata kunci: Materi Ajar, Digital, Open Office Sun Microsystem

\begin{abstract}
The main aim of this organized community service activities are: 1) to determine the level of knowledge of senior high school teachers in Ubud District on the existence of Open Office Sun Microsystems, 2) to determine the level of ability of senior high school teachers in Ubud District in making teaching materials in digital form. The method used in the implementation of this activity is the training method. The successful implementation of activity are evident from the results of tests of cognitive obtained by the trainees with the acquisition value of an average of 80.67 , the test results of practice with the acquisition value of an average of 81.60 , and the results of the responses given by the trainee through a questionnaire, with the acquisition of a percentage of $93.33 \%$.
\end{abstract}

Keywords: Teaching Materials, Digital, Open Office Sun Microsystem

\section{PENDAHULUAN}

Seiring perkembangan teknologi informasi dan komunikasi dewasa ini, tampak bahwa telah terjadi perubahan gaya hidup dan perilaku masyarakat. Saat ini, masyarakat cenderung menginginkan hal-hal yang praktis dan semua pekerjaan dapat terselesaikan dengan cepat melalui bantuan teknologi informasi dan komunikasi. Teknologi informasi dan komunikasi dapat digunakan di berbagai bidang untuk membantu pekerjaan masyarakat, mulai dari bidang ekonomi dan perbankan dengan munculnya teknologi e-commerce, e-trading dan ebanking, di bidang pemerintahan dengan munculnya teknologi e-government, serta di bidang pendidikan dengan munculnya teknologi e-learning. Pada prinsipnya teknologi informasi dan komunikasi itu dapat berjalan dengan baik dan optimal asalkan ada data yang dapat dengan mudah diolah menjadi suatu informasi sehingga dapat dipergunakan oleh pihakpihak yang membutuhkannya. Data yang dapat diolah dengan cepat oleh komputer adalah data yang berbentuk digital. Data yang berbentuk digital dapat berformat 
.pdf, .doc., .xml, .jpeg, .png dan lain sebagainya. Secara umum kebutuhan data berbentuk digital saat ini sangat tinggi di berbagai bidang kehidupan akibat perkembangan teknologi informasi dan secara khusus juga dirasakan pada bidang pendidikan. Kebutuhan data digital dalam dunia pendidikan biasanya digunakan untuk membantu proses pembelajaran dan kegiatan administratif lainnya yang menunjang pendidikan. Data digital digunakan sebagai bahan untuk membuat media pembelajaran, e-learning, dan kegiatan-kegiatan lainnya yang menunjang proses pendidikan. Kenyataan di lapangan ditemukan bahwa masih banyak pendidik yang belum bisa membuat data digital untuk keperluan pembelajaran ataupun keperluan administratif lainnya. Hal tersebut juga dirasakan di SMA sekecamatan Ubud yaitu SMA Negeri 1 Ubud dan SMA PGRI 3 Ubud yaitu masih rendahnya kemampuan guru-guru dalam membuat materi ajar berbentuk digital untuk keperluan pembelajaran. Dari hasil wawancara dengan Kepala Sekolah SMA Negeri 1 Ubud diperoleh data bahwa dari 100 jumlah guru yang ada, 80 orang guru $(80 \%)$ masih belum mampu membuat materi ajar berbentuk digital untuk keperluan pembelajaran, sedangkan di SMA PGRI 3 Ubud dari 40 guru yang ada, 35 orang guru $(87,50 \%)$ juga masih belum mampu membuat materi ajar berbentuk digital untuk keperluan pembelajaran. Dengan memperhatikan situasi tersebut maka tim pengabdian masyarakat sepakat dengan unit mitra yaitu SMA kecamatan Ubud, salah satunya dalam hal ini adalah melalui Kepala Sekolah SMA Negeri 1 Ubud untuk mengadakan pelatihan pembuatan materi ajar berbentuk digital untuk menunjang proses pembelajaran khususnya di SMA Negeri 1 Ubud. Sehingga nantinya ilmu yang diperoleh oleh guru-guru SMA Negeri 1 Ubud dapat ditularkan/diserbarkan kepada guru-guru di SMA/SMK lainnya yang ada di kecamatan Ubud. Tujuan utama diadakan kegiatan ini adalah: 1) untuk mengetahui tingkat pengetahuan yang dimiliki oleh para guru SMA yang ada di Kecamatan Ubud tentang keberadaan software open source yaitu open office sun microsystem untuk membuat materi ajar berbentuk digital,
2) untuk mengetahui tingkat kemampuan para guru SMA yang ada di kecamatan Ubud dalam membuat materi ajar berbentuk digital.

\section{TINJAUAN PUSTAKA}

\section{Open Source}

Open source merupakan adalah istilah yang digunakan untuk software yang membuka/membebaskan source codenya untuk dilihat oleh orang lain dan membiarkan orang lain mengetahui cara kerja software tersebut dan sekaligus memperbaiki kelemahan-kelemahan yang ada pada software tersebut. Dan yang menarik dan salah satu keunggulannya adalah bahwa Open source software dapat diperoleh dan digunakan secara gratis tanpa perlu membayar lisensi (http://www.opensource.org/).

Ketika seorang programmer dapat membaca, dapat mendistribusikan lagi dan memodifikasi kode program untuk sebagian software atau terlibat keseluruhan. Orang dapat meningkatkan, menyesuaikan, memperbaiki bug dari software tersebut (Rakhmawati, 2006).

\section{Open Office Sun Microsystem}

Open office sun microsystem adalah aplikasi perkantoran yang pertama mendukung penuh ODF. Open Office merupakan gabungan beberapa aplikasi yang dirumuskan dalam ODF, yakni teks atau pengolah kata (.odt), spreadsheet (.ods), presentasi (.odp), gambar (.odg), formula (.odf), dan database (.odb). Open Office tersedia untuk berbagai jenis sistem operasi seperti Linux, Mac OSX, MS Windows, dan Solaris. Sejak Open Office di bawah Oracle bersamaan dengan pengambil-alihan Sun Microsystems oleh Oracle, sebagian besar distro (distribution) atau varian Linux terbaru tidak lagi menyertakan Open Office, tetapi diganti dengan LibreOffice yang dikembangkan oleh pengembang Open Office. Pengguna Linux versi lama (2010 atau sebelumnya), masih dapat menggunakan Open Office tanpa harus menginstal karena telah tersedia dalam distro Linux itu. Pengguna Linux terbaru sebaiknya langsung menggunakan LibreOffice agar tidak direpotkan dengan proses instalasi Open Office, kecuali sangat membutuhkan Open 
Office karena alasan tertentu. (Peraturan Menteri Komunikasi dan Informatika RI No. 7 Tahun 2013).

Open Office Sun Microsystem adalah software open office terkemuka untuk pengolah kata, spreadsheet, presentasi, grafis, database dan lain-lain. Software ini tersedia dalam banyak bahasa dan bekerja pada semua komputer umum. la menyimpan semua data dalam format standar terbuka internasional dan juga dapat membaca dan menulis file dari paket perangkat lunak perkantoran umum lainnya. Software ini dapat didownload dan digunakan benar-benar gratis untuk tujuan apapun (http://www.openoffice.org/).

Open Office Sun Microsystem adalah hasil rekayasa perangkat lunak yang konsep pembangunannya benar-benar terbuka berarti siapapun dapat melaporkan bug, meminta fitur baru, atau meningkatkan perangkat lunak. Software ini mempunyai komponen antara lain:

a. Writer, yang dapat digunakan untuk pengolah kata apa pun mulai dari menulis surat cepat, bahkan untuk membuat sebuah buku.

b. Calc, yang dapat digunakan untuk menghitung, menganalisis, dan menyajikan data dalam laporan numerik.

c. Impress, yang dapat digunakan untuk membuat presentasi multimedia yang efektif.

d. Draw, yang dapat digunakan untuk menghasilkan segala sesuatu dari diagram sederhana menjadi ilustrasi 3D yang dinamis.

e. Base, yang dapat digunakan untuk memanipulasi database dengan cepat. Seperti: membuat dan memodifikasi tabel, form, query, dan report.

f. Math, yang dapat digunakan untuk membuat persamaan matematika dengan antarmuka pengguna grafis atau dengan langsung mengetik formula ke editor persamaan.

\section{METODE}

Metode yang digunakan dalam pelaksanaan kegiatan pembuatan materi ajar berbentuk digital melalui aplikasi open office sun microsystem bagi guru-guru SMA se-Kecamatan Ubud yaitu metode pelatihan, dengan tahapan-tahapan yang dilakukan antara lain: 1) tahap penentuan target kegiatan, 2) tahap penentuan kuota peserta, 3) tahap penyebaran surat undangan, 4) tahap prosedur peminjaman tempat pelatihan, 5) tahap persiapan tempat pelatihan, 6) tahap penyusunan materi dan modul pelatihan, 7) tahap pencetakan modul pelatihan, 8) tahap perencanaan dan penentuan jadwal pelatihan, 9) tahap pelaksanaan pelatihan, 10) tahap evaluasi pelatihan, 11) tahap pencetakan dan pengiriman sertifikat, dan 12) tahap penyusunan laporan P2M akhir.

\section{HASIL DAN PEMBAHASAN Hasil}

Adapun hasil yang diperoleh dari kegiatan pengabdian masyarakat ini, dapat dijelaskan sebagai berikut.

\section{Tahap Penentuan Target Kegiatan}

Jumlah SMA yang ditentukan sebanyak 1 SMA yaitu SMA Negeri 1 Ubud sebagai perwakilan dari seluruh SMA yang ada di kecamatan Ubud untuk mengikuti pelatihan pembuatan materi ajar berbentuk digital melalui aplikasi open office sun microsystem bagi guru-guru SMA seKecamatan Ubud.

\section{Tahap Penentuan Kuota Peserta}

Kuota peserta untuk mengikuti pelatihan pembuatan materi ajar berbentuk digital melalui aplikasi open office sun microsystem bagi guru-guru SMA seKecamatan Ubud sebanyak 10 orang.

\section{Tahap Penyebaran Surat Undangan}

Penyebaran surat undangan dilakukan dengan cara memberikan surat undangan kepada para peserta pelatihan yaitu sebanyak 10 orang peserta melalui Kepala SMA Negeri 1 Ubud.

\section{Tahap Prosedur Peminjaman Tempat Pelatihan}

Tempat/lokasi pelatihan pembuatan materi ajar berbentuk digital melalui aplikasi open office sun microsystem bagi guru-guru SMA se-Kecamatan Ubud dilaksanakan di Laboratorium SMA Negeri 1 Ubud. 


\section{Tahap Persiapan Tempat Pelatihan}

Persiapan tempat pelatihan dilakukan dengan pengecekan komputer dan pengecekan prasarana pendukung lainnya.

\section{Tahap Penyusunan Materi dan Modul Pelatihan}

Materi pokok yang diberikan dalam pelatihan pembuatan materi ajar berbentuk digital melalui aplikasi open office sun microsystem terdiri dari beberapa bagian antara lain:
a. Pengenalan Open Office Sun Microystem
b. Fitur-fitur Open Office Sun Microsystem
c. Proses Pembuatan Materi Ajar
d. Spreadsheet (Pengolah Angka)
e. Presentation (Pengolah Presentasi)

\section{Tahap Pencetakan Modul Pelatihan}

Modul pelatihan dicetak sesuai dengan maksimal kuota peserta pelatihan yaitu sebanyak 10 modul, dan 5 modul dibagikan gratis untuk guru-guru yang tidak mengikuti pelatihan agar dapat dipelajari sendiri nantinya ataupun diajarkan nantinya oleh peserta pelatihan setelah menyelesaikan pelatihan.

\section{Tahap Perencanaan dan Penentuan Jadwal Pelatihan}

Rencana pelatihan secara efektif dilaksanakan dalam 3 kali pertemuan selama 1 bulan dan $1 \times$ pertemuan. Tiap 1 kali pertemuan dilaksanakan dalam 6 jam yang dibagi menjadi 2 sesi yaitu sesi pertama selama 3 jam dan sesi kedua selama 3 jam. Pada pertemuan terakhir pelatihan, yaitu pada sesi keduanya dilaksanakan kegiatan ujian/tes untuk mengetahui kemampuan guru-guru dalam membuat suatu materi ajar berbentuk digital yang baik sesuai dengan bidang studi yang diajarnya, kemudian dilanjutkan pada pertemuan ke-4 untuk kegiatan pendampingan.

\section{Tahap Pelaksanaan Pelatihan}

Pelaksanaan pelatihan pada pertemuan pertama dimulai dari proses mengisi daftar hadir oleh peserta pelatihan, pembukaan keggiatan oleh Kepala Sekolah SMA Negeri 1 Ubud, laporan ketua panitia dan diikti proses perkenalan anggota panitia pelaksana, proses penyampaian materi yang diikuti dengan praktek langsung baik pada sesi 1 maupun sesi 2. Pelaksanaan pada pertemuan kedua dimulai dari proses mengisi daftar hadir oleh peserta pelatihan, proses penyampaian materi yang diikuti dengan praktek langsung baik pada sesi 1 maupun sesi 2. Pada pertemuan ketiga dimulai dari proses mengisi daftar hadir oleh peserta pelatihan, proses penyampaian materi yang diikuti dengan praktek langsung pada sesi 1 dan dilanjutkan kemudian dengan ujian/test pada sesi 2. Pada pertemuan keempat dimulai dari proses mengisi daftar hadir oleh peserta pelatihan, proses pendampingan, dan penutupan kegiatan oleh Kepala Sekolah SMA Negeri 1 Ubud. Adapun bukti dokumen pelaksanaan kegiatan dapat dilihat melalui gambar 1 berikut.

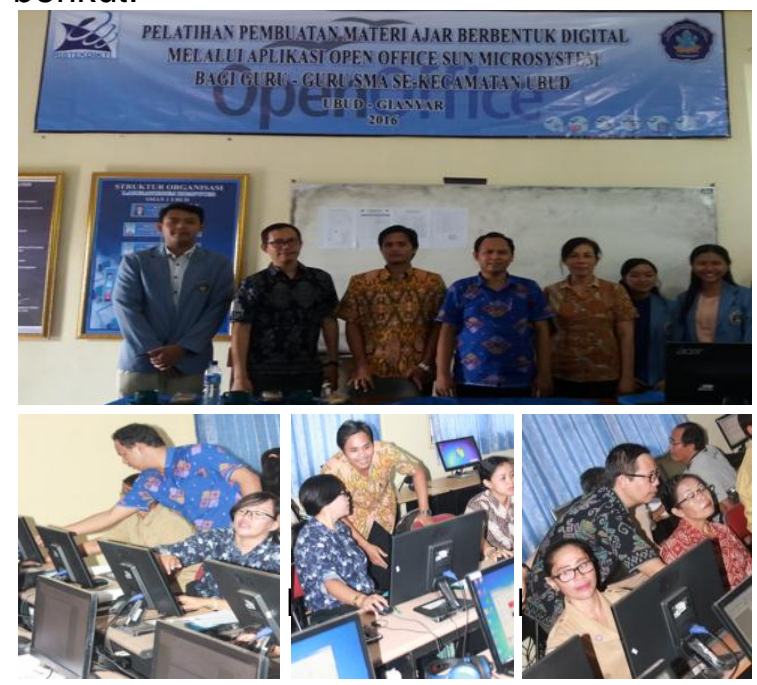

\section{Tahap Evaluasi Pelatihan}

Proses evaluasi ini dilakukan di akhir pertemuan. Tujuan dari proses evaluasi ini adalah untuk mengetahui respon dari peserta pelatihan dan capaian yang didapatkan dalam proses pelatihan ini. Adapun hasil capaian dan respon yang diberikan oleh peserta pelatihan pembuatan materi ajar berbentuk digital melalui aplikasi open office sun microsystem dapat dijelaskan sebagai berikut.

a. Tingkat pengetahuan peserta pelatihan tentang keberadaan software

Tingkat pengetahuan peserta pelatihan tentang keberadaan software dapat diketahui melalui test kognitif. Adapun hasil capaian yang diperoleh oleh peserta 
pelatihan dalam mengukur tingkat pengetahuannya tentang keberadaan software open source, dapat dilihat pada tabel 1 berikut ini.

Tabel 1. Tingkat Pengetahuan Peserta Pelatihan

\begin{tabular}{|c|c|c|c|}
\hline No & Nama Peserta & Nilai & Ket \\
\hline 1 & $\begin{array}{l}\text { Dra. Anak Agung Alit Sri, } \\
\text { M.Pd }\end{array}$ & 80,00 & Baik \\
\hline 2 & $\begin{array}{l}\text { I Wayan Ubud, S.Pd, } \\
\text { M.Pd }\end{array}$ & 73,33 & Baik \\
\hline 3 & $\begin{array}{l}\text { Gusti Ayu Suarsani, } \\
\text { S.Pd, M.Pd }\end{array}$ & 73,33 & Baik \\
\hline 4 & $\begin{array}{l}\text { I Nyoman Lanus Widana, } \\
\text { S.Pd, M.Pd }\end{array}$ & 93,33 & $\begin{array}{l}\text { Sangat } \\
\text { Baik }\end{array}$ \\
\hline 5 & I Nyoman Sujaya, S.Pd & 80,00 & Baik \\
\hline 6 & $\begin{array}{l}\text { Anak Agung Gde Alit, } \\
\text { S.Pd }\end{array}$ & 86,67 & $\begin{array}{l}\text { Sangat } \\
\text { Baik }\end{array}$ \\
\hline 7 & $\begin{array}{l}\text { Ida Bagus Ketut } \\
\text { Suardiana, S.Pd }\end{array}$ & 80,00 & Baik \\
\hline 8 & $\begin{array}{l}\text { I Nyoman Sudiartha, } \\
\text { S.Pd, M.Pd }\end{array}$ & 86,67 & $\begin{array}{l}\text { Sangat } \\
\text { Baik }\end{array}$ \\
\hline 9 & $\begin{array}{l}\text { Desak Nyoman } \\
\text { Sukanestri, S.Pd, M.Pd }\end{array}$ & 80,00 & Baik \\
\hline \multirow[t]{2}{*}{10} & $\begin{array}{l}\text { I Wayan Sumertayasa, } \\
\text { ST }\end{array}$ & 73,33 & Baik \\
\hline & Rata-rata & 80,67 & Baik \\
\hline
\end{tabular}

b. Tingkat kemampuan peserta pelatihan dalam membuat materi ajar berbentuk digital

Tingkat kemampuan peserta pelatihan dalam membuat materi ajar berbentuk digital dapat diketahui melalui test praktek. Adapun hasil capaian yang diperoleh oleh peserta pelatihan dalam mengukur kemampuannya membuat materi ajar berbentuk digital, dapat dilihat pada tabel 2 berikut.

Tabel 2. Tingkat Kemampuan Peserta Pelatihan

\begin{tabular}{|c|l|c|l|}
\hline No & \multicolumn{1}{|c|}{ Nama Peserta } & Nilai & \multicolumn{1}{|c|}{ Ket } \\
\hline 1 & $\begin{array}{l}\text { Dra. Anak Agung Alit Sri, } \\
\text { M.Pd }\end{array}$ & 82,00 & Baik \\
\hline 2 & I Wayan Ubud, S.Pd, M.Pd & 78,00 & Baik \\
\hline 3 & $\begin{array}{l}\text { Gusti Ayu Suarsani, S.Pd, } \\
\text { M.Pd }\end{array}$ & 75,00 & Baik \\
\hline 4 & $\begin{array}{l}\text { I Nyoman Lanus Widana, } \\
\text { S.Pd, M.Pd }\end{array}$ & 88,00 & $\begin{array}{l}\text { Sangat } \\
\text { Baik }\end{array}$ \\
\hline 5 & I Nyoman Sujaya, S.Pd & 82,00 & Baik \\
\hline 6 & Anak Agung Gde Alit, S.Pd & 88,00 & $\begin{array}{l}\text { Sangat } \\
\text { Baik }\end{array}$ \\
\hline 7 & $\begin{array}{l}\text { Ida Bagus Ketut } \\
\text { Suardiana, S.Pd }\end{array}$ & 84,00 & Baik \\
\hline 8 & $\begin{array}{l}\text { I Nyoman Sudiartha, S.Pd, } \\
\text { M.Pd }\end{array}$ & 80,00 & $\begin{array}{l}\text { Sangat } \\
\text { Baik }\end{array}$ \\
\hline
\end{tabular}

\begin{tabular}{|c|l|c|c|}
\hline No & \multicolumn{1}{|c|}{ Nama Peserta } & Nilai & Ket \\
\hline 9 & $\begin{array}{l}\text { Desak Nyoman Sukanestri, } \\
\text { S.Pd, M.Pd }\end{array}$ & 84,00 & Baik \\
\hline 10 & I Wayan Sumertayasa, ST & 75,00 & Baik \\
\hline & Rata-rata & $\mathbf{8 1 , 6 0}$ & Baik \\
\hline
\end{tabular}

c. Respon yang diberikan oleh peserta pelatihan terhadap kegiatan pelatihan pembuatan materi ajar berbentuk digital melalui aplikasi open office sun microsystem

Respon yang diberikan oleh peserta pelatihan terhadap kegiatan pelatihan pembuatan materi ajar berbentuk digital melalui aplikasi open office sun microsystem dapat diketahui melalui pengisian angket respon peserta pelatihan. Adapun hasil respon yang diberikan oleh peserta pelatihan terhadap kegiatan pelatihan pembuatan materi ajar berbentuk digital melalui aplikasi open office sun microsystem, dapat dilihat pada tabel 3 berikut.

Tabel 3. Angket Respon Peserta Pelatihan

\begin{tabular}{|c|c|c|c|c|c|c|c|c|c|}
\hline \multirow{2}{*}{ No } & \multirow{2}{*}{ Resp } & \multicolumn{5}{|c|}{ Nomor Butir } & \multirow{2}{*}{$\mathrm{Jml}$} & \multirow{2}{*}{$\%$} & \multirow{2}{*}{$\begin{array}{c}\text { Krite } \\
\text { ria }\end{array}$} \\
\hline & & 1 & 2 & 3 & 4 & 5 & & & \\
\hline 1 & $\mathrm{I}$ & 3 & 3 & 2 & 3 & 3 & 14 & 93 & SB \\
\hline 2 & II & 2 & 3 & 2 & 3 & 2 & 12 & 80 & $B$ \\
\hline 3 & III & 2 & 3 & 2 & 3 & 2 & 12 & 80 & $B$ \\
\hline 4 & IV & 3 & 3 & 2 & 3 & 3 & 14 & 93 & SB \\
\hline 5 & $\mathrm{~V}$ & 3 & 2 & 3 & 3 & 3 & 14 & 93 & SB \\
\hline 6 & VI & 3 & 3 & 2 & 2 & 3 & 13 & 87 & $B$ \\
\hline 7 & VII & 3 & 3 & 2 & 3 & 3 & 14 & 93 & SB \\
\hline 8 & VIII & 3 & 2 & 3 & 3 & 2 & 13 & 87 & $B$ \\
\hline 9 & IX & 3 & 3 & 2 & 3 & 3 & 14 & 93 & SB \\
\hline 10 & $\bar{X}$ & 2 & 3 & 2 & 3 & 2 & 12 & 80 & $B$ \\
\hline \multicolumn{2}{|c|}{$\begin{array}{c}\text { Jml Per } \\
\text { Butir }\end{array}$} & 27 & 28 & 22 & 29 & 26 & 132 & & \\
\hline \multicolumn{2}{|c|}{$\%$} & 90 & 93 & 73 & 97 & 87 & & & \\
\hline \multicolumn{2}{|c|}{ Kriteria } & SB & SB & B & SB & SB & & & \\
\hline \multicolumn{8}{|c|}{ Total Prosentase } & 880 & \\
\hline \multicolumn{8}{|c|}{ Rata-rata } & 88 & Baik \\
\hline
\end{tabular}

\section{Tahap Pencetakan dan Pengiriman Sertifikat}

Sertifikat yang telah dicetak, selanjutnya diberikan ke masing-masing peserta pelatihan maksimal 1 minggu setelah pelatihan dilakukan. Adapun salah satu bentuk sertifikat yang diberikan kepada peserta pelatihan dapat dilihat pada gambar 2 berikut. 

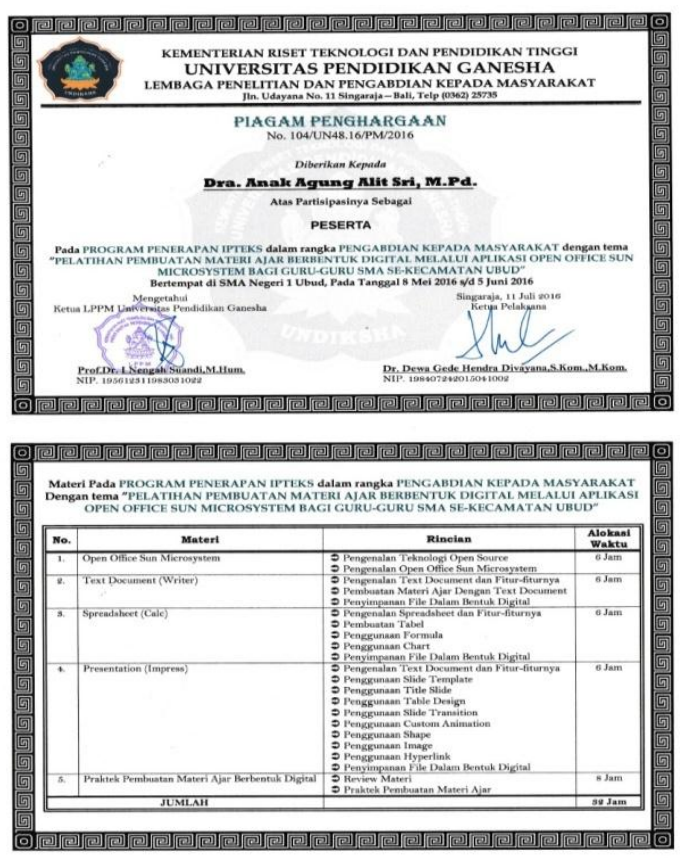

Gambar 2. Sertifikat Pelatihan

\section{Tahap Penyusunan Laporan P2M Akhir}

Hasil akhir dari pelatihan seperti dokumentasi dan respon peserta, dijadikan sebagai laporan akhir dari pelaksanaan P2M. Disamping laporan akhir, dilampirkan juga bukti tugas/karya utama yang telah dikerjakan oleh peserta pelatihan berupa softcopy materi ajar berbentuk digital yang disimpan dalam CD-R dan hardcopynya. Adapun beberapa bukti karya utama yang telah dikerjakan/dihasilkan oleh peserta pelatihan dapat dilihat pada gambar 3 berikut.

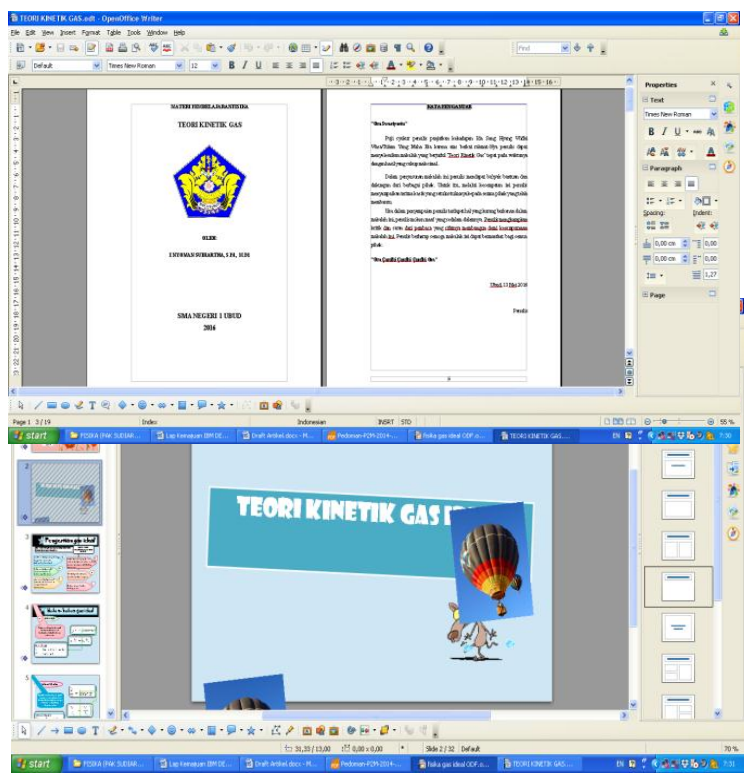

Gambar 3. Hasil Karya Peserta Pelatihan
Pembahasan

Berdasarkan hasil kegiatan yang telah dijelaskan sebelumnya, maka ada beberapa hal yang akan tim pelaksana bahas tentang hasil kegiatan pengabdian masyarakat ini, antara lain sebagai berikut.

1. Tingkat pengetahuan para guru SMA yang ada di kecamatan Ubud tentang keberadaan software open source yaitu open office sun microsystem untuk membuat materi ajar berbentuk digital.

Dari hasil capaian yang diperoleh oleh peserta pelatihan dalam mengukur tingkat pengetahuannya tentang keberadaan software open source melalui test kognitif, maka diperoleh nilai rata-rata sebesar 80,67 . Hal ini berarti bahwa secara umum tingkat pengetahuan para guru SMA yang ada di kecamatan Ubud tentang keberadaan software open source yaitu open office sun microsystem untuk membuat materi ajar berbentuk digital sudah termasuk kategori baik, karena mereka sudah mampu menjawab dengan baik beberapa pertanyaan tentang teknologi open source, open office sun microsystem, text document dan fiturfiturnya, spreadsheet dan fitur-fiturnya, presentation dan fitur-fiturnya.

Dari hasil respon yang diberikan oleh peserta pelatihan dalam mengukur tingkat pengetahuannya tentang keberadaan software open source melalui angket, maka diperoleh nilai prosentase respon yang diberikan oleh peserta pelatihan untuk butir 1 tentang keberadaan software open source sebesar $90,00 \%$. Hal ini juga berarti bahwa secara umum tingkat pengetahuan para guru SMA yang ada di kecamatan Ubud tentang keberadaan software open source yaitu open office sun microsystem untuk membuat materi ajar berbentuk digital sudah termasuk kategori sangat baik.

2. Tingkat kemampuan para guru SMA yang ada di kecamatan Ubud membuat materi ajar berbentuk digital menggunakan software open office sun microsystem

Dari hasil capaian yang diperoleh oleh peserta pelatihan dalam mengukur tingkat kemampuannya membuat materi ajar berbentuk digital menggunakan software open office sun microsystem melalui test praktek membuat materi ajar berbentuk 
digital, maka diperoleh nilai rata-rata sebesar 81,60. Hal ini berarti bahwa secara umum tingkat kemampuan para guru SMA yang ada di kecamatan Ubud dalam membuat materi ajar berbentuk digital menggunakan software open office sun microsystem sudah termasuk kategori baik, karena mereka sudah mampu membuat sendiri materi ajar berbentuk digital dengan software open office sun microsystem, khususnya menggunakan fasilitas text document dan presentation.

Dari hasil respon yang diberikan oleh peserta pelatihan dalam mengukur tingkat kemampuannya dalam membuat materi ajar berbentuk digital melalui angket, maka diperoleh nilai prosentase respon yang diberikan oleh peserta pelatihan untuk butir 2 tentang penggunaan text document sebagai dasar dalam membuat materi ajar berbentuk digital sebesar 93,33\%. Hal ini juga berarti bahwa secara umum tingkat kemampuan para guru SMA yang ada di kecamatan Ubud dalam melakukan pengolahan kata yang nantinya digunakan sebagai dasar untuk membuat materi ajar berbentuk digital sudah termasuk kategori sangat baik. Nilai prosentase respon yang diberikan oleh peserta pelatihan untuk butir 3 tentang penggunaan spreadsheet sebagai dasar dalam membuat materi ajar berbentuk digital sebesar $73,33 \%$. Hal ini juga berarti bahwa secara umum tingkat kemampuan para guru SMA yang ada di kecamatan Ubud dalam melakukan pengolahan angka yang nantinya digunakan sebagai dasar untuk membuat materi ajar berbentuk digital sudah termasuk kategori baik. Nilai prosentase respon yang diberikan oleh peserta pelatihan untuk butir 4 tentang penggunaan presentation sebagai dasar dalam membuat materi ajar berbentuk digital sebesar 96,67\%. Hal ini juga berarti bahwa secara umum tingkat kemampuan para guru SMA yang ada di kecamatan Ubud dalam melakukan pengolahan slide presentasi yang nantinya digunakan sebagai dasar untuk membuat materi ajar berbentuk digital sudah termasuk kategori sangat baik. Nilai prosentase respon yang diberikan oleh peserta pelatihan untuk butir 5 tentang tingkat keyakinan peserta pelatihan dalam membuat materi ajar berbentuk digital menggunakan aplikasi open source sun microsystem sebesar $86,67 \%$. Hal ini juga berarti bahwa secara umum tingkat keyakinan yang dimiliki para guru SMA yang ada di kecamatan Ubud dalam membuat materi ajar berbentuk digital sudah termasuk kategori sangat baik.

\section{KESIMPULAN}

Guru-guru se-Kecamatan Ubud yang diwakili oleh guru-guru SMA Negeri 1 Ubud menyambut baik dan antusias mengikuti kegiatan pelatihan pembuatan materi ajar berbentuk digital melalui aplikasi open office sun microsystem ini karena mereka sangat membutuhkan pengetahuan dan keterampilan dalam membuat materi ajar digital untuk membantu kegiatan pembelajaran.

\section{DAFTAR PUSTAKA}

Peraturan Menteri Komunikasi dan Informatika RI No. 7 Tahun 2013.

Rakhmawati, N A. 2006. Software Open Source, Software Gratis?, JUTI Vol. 5, No.1, Januari 2006, h. 13-18.

Wirawan, I.M.A. 2013. Laporan Akhir P2M, IbM Pelatihan Desain Grafis Untuk Anak-anak Panti Asuhan seKecamatan Buleleng. Singaraja: Universitas Pendidikan Ganesha. http://www.opensource.org/ http://www.openoffice.org/ 